\title{
Gas exchange, growth, and production of mini-watermelon under saline water irrigation and phosphate fertilization
}

\section{Trocas gasosas, crescimento e produção de mini-melancieira irrigada com águas salinas e adubação fosfatada}

\author{
Geovani Soares de Lima ${ }^{1 *}$; Charles Macedo Félix²; Saulo Soares da Silva \\ Lauriane Almeida dos Anjos Soares ${ }^{4}$; Hans Raj Gheyi ${ }^{1}$; Marcos Denilson Melo \\ Soares $^{2}$; Pedro Francisco do Nascimento Sousa ${ }^{2}$; Pedro Dantas Fernandes ${ }^{1}$
}

\section{Highlights:}

Phosphorus doses did not mitigate the effects of salt stress on gas exchange and growth. The $\mathrm{CO}_{2}$ assimilation rate was limited by factors of non-stomatal and stomatal origin. Mini-watermelon production is drastically reduced by water salinity.

\begin{abstract}
In the semi-arid region of Northeastern Brazil, due to the occurrence of excess salts, both in the water and soil, plants are constantly exposed to various conditions of abiotic stress. Thus, it is extremely important to identify methods capable of minimizing the effects of salt stress on plants as a way to ensure the expansion of irrigated areas. In this context, the objective of this study was to evaluate the gas exchange, growth, and production of mini-watermelon irrigated with saline waters and fertilized with phosphorus. The experiment was conducted in pots under greenhouse conditions in Pombal, PB, Brazil, using a randomized block design in a $5 \times 4$ factorial scheme, corresponding to five levels of electrical conductivity of irrigation water- $\mathrm{ECw}\left(0.3,1.3,2.3,3.3\right.$, and $\left.4.3 \mathrm{dS} \mathrm{m}^{-1}\right)$, four phosphorus dosesPD (60, 80, 100, and $120 \%$ of the recommendation), and with three replicates. Watermelon plants cv. Sugar Baby were sensitive to water salinity greater than $0.3 \mathrm{dS} \mathrm{m}^{-1}$, with more pronounced inhibition of gas exchange, growth, and production. Reduction in the $\mathrm{CO}_{2}$ assimilation rate of watermelon plants cv. Sugar Baby was associated with factors of stomatal and non-stomatal origin. Phosphorous doses corresponding to 73 and $88 \%$ of the recommended values promoted an increase in the intercellular $\mathrm{CO}_{2}$ concentration and stem diameter of mini-watermelon plants. $\mathrm{P}_{2} \mathrm{O}_{5}$ doses ranging from 60 to $120 \%$ of the recommendation did not mitigate the effects of salt stress on the cultivation of watermelon cv. Sugar Baby.
\end{abstract}

Key words: Citrullus lanatus. Salt stress. Semi-arid region.

1 Profs., Programa de Pós-Graduação em Engenharia Agrícola, Centro de Tecnologia e Recursos Naturais, Universidade Federal de Campina Grande, UFCG, Campina Grande, PB, Brasil. E-mail: geovani.soares@pq.cnpq.br; hans@pq.cnpq.br; pedrodantasfernandes@gmail.com

2 Discentes do Curso de Graduação em Agronomia, UFCG, Centro de Ciências e Tecnologia Agroalimentar, Pombal, PB, Brasil. E-mail: charlesmacedo072@gmail.com; marquinhosigt078@gmail.com; pedritocpn22@gmail.com

3 Discente do Curso de Doutorado do Programa de Pós-Graduação em Engenharia Agrícola, UFCG, Centro de Tecnologia e Recursos Naturais, Campina Grande, PB, Brasil. E-mail: saulosoares90@gmail.com

4 Prof ${ }^{a}$, Unidade Acadêmica de Ciências Agrárias, UFCG, Pombal, PB, Brasil. E-mail: lauriane.soares@pq.cnpq.br

* Author for correspondence

Received: Apr. 20, 2020 - Approved: Aug, 24, 2020 


\section{Resumo}

No semiárido do Nordeste brasileiro devido à ocorrência do excesso de sais, tanto na água como no solo, as plantas estão constantemente expostas às diversas condições de estresses abióticos. Assim, é de extrema importância a identificação de alternativas capazes de minimizar os efeitos decorrentes do estresse salino sobre as plantas como forma de garantir a expansão das áreas irrigadas. Neste contexto, objetivou-se com este trabalho avaliar as trocas gasosas, o crescimento e a produção de mini-melancieira irrigada com águas salinas e adubadas com fósforo. A pesquisa foi desenvolvida em vasos sob condições de casa-de-vegetação em Pombal, PB, utilizando-se o delineamento de blocos casualizados em esquema fatorial $5 \times 4$, correspondendo a cinco níveis de condutividade elétrica da água de irrigação - CEa ( 0,3 ; 1,$3 ; 2,3 ; 3,3$ e $\left.4,3 \mathrm{dS} \mathrm{m}^{-1}\right)$, quatro doses de fósforo - DP $(60 ; 80 ; 100$ e $120 \%$ da recomendação), com três repetições. As plantas de melancieira cv. Sugar Baby foram sensíveis a salinidade da água a partir de $0,3 \mathrm{dS} \mathrm{m}^{-1}$, destacando-se inibição nas trocas gasosas, no crescimento e na produção. A redução na taxa de assimilação de $\mathrm{CO}_{2}$ nas plantas de melancieira cv. Sugar Baby está associado a fatores de origem estomáticos e não estomáticos. Doses de fosforo correspondente a 73 e $88 \%$ da recomendação promoveram aumento na concentração intercelular de $\mathrm{CO}_{2}$ e no diâmetro de caule das plantas de minimelancia. Doses de $\mathrm{P}_{2} \mathrm{O}_{5}$ variando de 60 a $120 \%$ da recomendação não amenizou os efeitos do estresse salino no cultivo da melancieira cv. Sugar Baby.

Palavras-chave: Citrullus lanatus. Estresse salino. Semiárido.

\section{Introduction}

Belonging to the Cucurbitaceae family, watermelon (Citrullus lanatus) is considered one of the most important vegetables produced and commercialized in Brazil. Its fruits are appreciated for the sweet taste and high water content, and it is considered a medicinal plant with diuretic properties, low caloric value, and is high in vitamins A, C, B1, and B2 (Saraiva et al., 2013). Among the varieties of watermelon, mini-watermelon has stood out in the market because of its potential for export and mainly attracts consumers who make up small families, due to its practicality in terms of transport, its reduced size, and ease of packaging in refrigerators (N. C. Silva et al., 2008).

In the 2018 season, the five largest Brazilian producers in terms of harvested area were the states of Rio Grande do Norte (15,862 ha), Bahia (14,349 ha), Rio Grande do Sul (14,212 ha), São Paulo (10,173 ha) and Tocantins (6,369 ha), corresponding to average yields of $24.68,11.66,19.95,27.68$ and $28.13 \mathrm{t} \mathrm{ha}^{-1}$, respectively (Instituto Brasileiro de Geografia e Estatística [IBGE], 2018). Although some states in Northeastern Brazil stand out as the largest producers, the cultivation of this vegetable in areas of the Brazilian semi-arid region is at risk due to the variation in rainfall, resulting from the low intensity of precipitation and high rates of evapotranspiration during most of the year (Araújo et al., 2016).

Due to the scarcity of water in semi-arid areas of Northeastern Brazil, it is essential to adopt the practice of irrigation with saline waters to ensure crop production and expansion of irrigated areas (Alvarenga et al., 2019). Normally, the water sources available for irrigation in this region are small and medium-sized reservoirs and shallow wells, with electrical conductivity ranging from 1.97 to 2.98 $\mathrm{dS} \mathrm{m}^{-1}$ (Medeiros, Lisboa, Oliveira, Silva, \& Alves, 2003).

High concentrations of salts in water and/or soil can cause changes in various physiological and metabolic processes in plants (Gupta \& Huang, 2014). This is due to the reduction in water availability for plants caused by the osmotic effect of the soil solution; this toxic effect occurs mainly due to the increased concentration of $\mathrm{Na}^{+}$and $\mathrm{Cl}^{-}$ ions and resulting nutritional imbalance, leading to deficiencies in $\mathrm{Ca}^{2+}, \mathrm{Mg}^{2+}, \mathrm{K}^{+}$, and $\mathrm{NO}_{3}^{-}$(Machado $\&$ Serralheiro, 2017). In addition, it manifests as an 
oxidative stress at the subcellular level, mediated by reactive oxygen species (Hernández, 2019).

In this case, the use of these waters is conditional on the tolerance of crops to salinity, and the management practices such as irrigation and fertilization (Freitas, Figueirêdo, Porto, Costa, \& Cunha, 2014). Thus, fertilization with phosphorus is extremely important in plants grown under salt stress conditions. This is related to the functions that phosphorus performs in plant metabolism, especially in terms of its capacity to store energy (F. R. A. Oliveira, Oliveira, Medeiros, Sousa, \& Freire, 2010), being essential in a number of cellular processes, including the maintenance of membrane structures, synthesis of biomolecules, and formation of high-energy molecules. It also helps in cell division, enzyme activation/inactivation, and carbohydrate metabolism (Razaq, Zhang, Shen, \& Salahuddin, 2017).

Considering the socioeconomic importance of watermelon, especially mini-watermelon, it is important to conduct studies investigating phosphate fertilization as a way to mitigate the effects of salt stress on this crop, under the conditions of the Brazilian semi-arid region. In this context, the objective of this study was to evaluate the gas exchange, growth, and production of miniwatermelon cv. Sugar Baby cultivated with saline water and phosphorus fertilization.

\section{Materials and Methods}

The experiment was carried out in a protected environment (greenhouse) at the Center for Sciences and Agri-Food Technology (CCTA) of the Federal University of Campina Grande (UFCG), located in the municipality of Pombal, PB, Brazil, at the geographic coordinates of $6^{\circ} 47^{\prime} 20^{\prime \prime} \mathrm{S}$ latitude and $37^{\circ} 48^{\prime} 01$ " W longitude, and an altitude of $194 \mathrm{~m}$.

Five levels of irrigation water electrical conductivity- $\mathrm{ECw}(0.3,1.3,2.3,3.3$, and $4.3 \mathrm{dS}$ $\left.\mathrm{m}^{-1}\right)$ and four doses of phosphorus $(60,80,100$, and
$120 \%$ of the recommended levels of Novais, Neves e Barros (1991) for experiments in pots) were evaluated in a randomized block design, arranged in a $5 \times 4$ factorial scheme with three replicates, with each plot consisting of one plant. The dose relative to $100 \%$ corresponded to $300 \mathrm{mg}$ of $\mathrm{P}_{2} \mathrm{O}_{5} \mathrm{~kg}^{-1}$ of soil.

Watermelon (Citrullus lanatus), cultivar Sugar Baby, was used in the experiment. This cultivar stands out for its early cycle, and the fruits are ready for harvesting 75 days after planting. It is a versatile plant with vigorous foliage and is tolerant to high temperatures. It produces round fruits with a dark green rind, weighing around 2 to $4 \mathrm{~kg}$. It has a soft pulp with high sugar content and an intense red color (S. S. da Silva et al., 2019).

Plants were cultivated in $20-\mathrm{L}$ plastic pots adapted as lysimeters. Two holes were made at the base of the pots and connected to transparent 4-mm-diameter drains. The end of the drain inside the lysimeter was connected to a nonwoven geotextile (Bidim OP 30) to prevent clogging by soil material. A container was placed below each drain to collect the drained water and estimate water consumption by plants. The pots were filled with a $0.5-\mathrm{kg}$ layer of crushed stone, followed by $23.5 \mathrm{~kg}$ of a Neossolo Regolitico (Psamment) with a sandy clay loam texture, from the rural area of the municipality of São Domingos, PB, whose chemical and physical characteristics (Table 1) were obtained according to the methodology proposed by Teixeira, Donagemma, Fontana e Teixeira (2017).

Four seeds of the watermelon cv. Sugar Baby were equidistantly distributed in each lysimeter, at $2 \mathrm{~cm}$ depth. After the emergence of seedlings, thinning was performed in two stages, when the plants had two and three pairs of true leaves, respectively, leaving one plant per container in the last thinning operation. 
Table 1

Chemical and physical characteristics of the soil used in the experiment, before the application of the treatments

\begin{tabular}{|c|c|c|c|c|c|c|c|c|}
\hline \multicolumn{9}{|c|}{ Chemical characteristics } \\
\hline $\left.\mathrm{pH} \mathrm{H}_{2} \mathrm{O}\right)$ & $\mathrm{OM}$ & $\mathrm{P}$ & $\mathrm{K}^{+}$ & $\mathrm{Na}^{+}$ & $\mathrm{Ca}^{2+}$ & $\mathrm{Mg}^{2+}$ & $\mathrm{Al}^{3+}$ & $\mathrm{H}^{+}$ \\
\hline$(1: 2,5)$ & $\mathrm{g} \mathrm{kg}^{-1}$ & $\left.(\mathrm{mg} \mathrm{kg})^{-1}\right)$ & \multicolumn{6}{|c|}{ 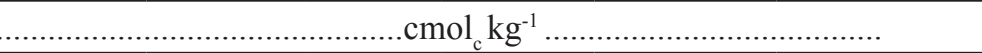 } \\
\hline 5.58 & 2.93 & 39.2 & 0.23 & 1.64 & 9.07 & 2.78 & 0.00 & 8.61 \\
\hline \multicolumn{4}{|c|}{.......... Chemical characteristics............. } & \multicolumn{5}{|c|}{  } \\
\hline $\mathrm{EC}_{\mathrm{se}}$ & $\mathrm{CEC}$ & SAR & ESP & \multicolumn{3}{|c|}{ Size fraction $\left(\mathrm{g} \mathrm{kg}^{-1}\right)$} & \multicolumn{2}{|c|}{ Water content $\left(\right.$ dag $\left.\mathrm{kg}^{-1}\right)$} \\
\hline$\left.(\mathrm{dS} \mathrm{m})^{-1}\right)$ & $\mathrm{cmol}_{\mathrm{c}} \mathrm{kg}^{-1}$ & $\left(\mathrm{mmol} \mathrm{L}^{-1}\right)^{0.5}$ & $\%$ & Sand & Silt & Clay & $33.42 \mathrm{kPa}^{1}$ & $1519.5 \mathrm{kPa}^{2}$ \\
\hline 2.15 & 22.33 & 0.67 & 7.34 & 572.70 & 100.70 & 326.60 & 25.91 & 12.96 \\
\hline
\end{tabular}

$\mathrm{pH}$ - Hydrogen potential, $\mathrm{OM}$ - Organic matter: Walkley-Black Wet Digestion; $\mathrm{Ca}^{2+}$ and $\mathrm{Mg}^{2+}$ extracted with $1 \mathrm{M} \mathrm{KCl}$ at $\mathrm{pH}$ 7.0; $\mathrm{Na}^{+}$and $\mathrm{K}^{+}$extracted with $1 \mathrm{M} \mathrm{NH}_{4} \mathrm{OAc}$ at $\mathrm{pH} 7.0 ; \mathrm{Al}^{3+}+\mathrm{H}^{+}$extracted with $0.5 \mathrm{M} \mathrm{CaOAc}$ at $\mathrm{pH}$ 7.0; ECse - Electrical conductivity of the saturation extract; $\mathrm{CEC}$ - Cation exchange capacity; SAR - Sodium adsorption ratio of the saturation extract; ESP - Exchangeable sodium percentage; ${ }^{1,2}$ referring to the limits of field capacity and permanent wilting point, respectively.

The waters were prepared in such a way as to have an equivalent proportion of $7: 2: 1$ of $\mathrm{Na}^{+}: \mathrm{Ca}^{2+}: \mathrm{Mg}^{2+}$, respectively, with the salts $\mathrm{NaCl}, \mathrm{CaCl}_{2} \cdot 2 \mathrm{H}_{2} \mathrm{O}$, and $\mathrm{MgCl}_{2} \cdot 6 \mathrm{H}_{2} \mathrm{O}$. This is the predominant ratio in sources of water used for irrigation in small farms in the Northeast region, considering the relationship between $\mathrm{ECW}$ and concentration of salts, according to Richards (1954), Eq. 1:

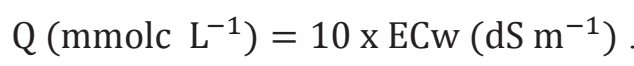

Where:

$\mathrm{Q}=$ Quantity of salts to be applied $\left(\mathrm{mmol}_{\mathrm{c}} \mathrm{L}^{-1}\right)$;

$\mathrm{ECw}=$ Electrical conductivity of water $\left(\mathrm{dS} \mathrm{m}^{-1}\right)$

Irrigation was performed daily at 17:00 h, applying in each container the volume corresponding to that obtained by the water balance, determined by Eq. 2:

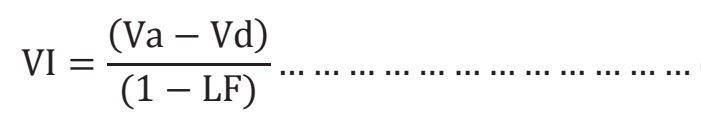

Where: VI = Volume of water to be applied $(\mathrm{mL})$; $\mathrm{Va}=$ volume applied in the previous irrigation event $(\mathrm{mL}) ; \mathrm{Vd}=$ volume drained $(\mathrm{mL})$, and $\mathrm{LF}=$ leaching fraction of 0.2 .
Fertilization with nitrogen and potassium was performed as recommended for pot experiments (Novais et al., 1991), applying via fertigation, at 15day intervals distributed throughout the crop cycle, 100 and $150 \mathrm{mg} \mathrm{kg}^{-1}$ soil of $\mathrm{N}$ and $\mathrm{K}_{2} \mathrm{O}$, respectively. Urea $(45 \% \mathrm{~N})$ and potassium chloride $\left(60 \% \mathrm{~K}_{2} \mathrm{O}\right)$ were used as sources of nitrogen and potassium, respectively.

P supply was performed according to preestablished treatments, using monoammonium phosphate $\left(48 \% \mathrm{P}_{2} \mathrm{O}_{5}\right)$, applying one third of the recommended dose as a basal level and the other two thirds in three equal applications, at 10-day intervals, with the first application at 15 days after sowing. Fertilization with micronutrients was performed weekly, and was applied through the foliar application using $1.0 \mathrm{~g} \mathrm{~L}^{-1}$ of Ubyfol [(N (15\%), $\mathrm{P}_{2} \mathrm{O}_{5}(15 \%), \mathrm{K}_{2} \mathrm{O}(15 \%), \mathrm{Ca}(1 \%), \mathrm{Mg}$ (1.4\%), S (2.7\%), Zn (0.5\%), B (0.05\%), Fe (0.5\%), $\mathrm{Mn}(0.05 \%), \mathrm{Cu}(0.5 \%)$, Mo (0.02\%)].

The effects of treatments on the crop were determined at 60 days after transplanting, through measuring gas exchange $\left(\mathrm{CO}_{2}\right.$ assimilation rate $(A)$, transpiration $(E)$, stomatal conductance $(g s)$ and intercellular $\mathrm{CO}_{2}$ concentration $(\mathrm{Ci})$ ) on the third leaf counted from the apex. Based on these 
data, the intrinsic water use efficiency (WUEi)

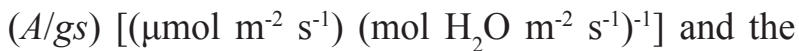
instantaneous carboxylation efficiency $(\mathrm{A} / \mathrm{Ci})$

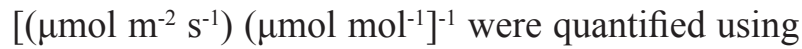
the portable photosynthesis meter "LCPro+" from ADC BioScientific Ltd.

Growth was evaluated based on main stem length (MSL), stem diameter (SD), and number of leaves (NL). Production components were measured at 70 days after sowing (DAS) by determining fruit equatorial diameter (FED), fruit polar diameter (FPD), and fresh fruit weight (FFW). MSL was measured as the distance between the plant collar and the insertion of the apical meristem, while SD was measured at $5 \mathrm{~cm}$ from the plant collar, while NL was counted considering leaves that were fully expanded, with a minimum length of $3 \mathrm{~cm}$ and with at least $50 \%$ of their area photosynthetically active. Fruit fresh weight was analyzed using a digital scale, and the results were expressed in g per plant.
The collected data were subjected to an analysis of variance by $F$ test at a probability level of 0.05 and, when significant, linear and quadratic polynomial regression analysis was performed for the factors salinity level and phosphorus dose, using the statistical program SISVAR ESAL (Ferreira, 2019).

\section{Results and Discussion}

According to the summary of the analysis of variance (Table 2), there was a significant effect of the interaction between factors (SL $x$ PD) on the $\mathrm{CO}_{2}$ assimilation rate $(A)$ and instantaneous carboxylation efficiency (CEi) of mini-watermelon plants. Except for $C E i$, the water salinity levels significantly influenced all the variables evaluated. Phosphorus doses had a significant effect only on intercellular $\mathrm{CO}_{2}$ concentration $(\mathrm{Ci})$ and the instantaneous carboxylation efficiency of miniwatermelon plants, at 70 days after sowing.

Table 2

Summary of the analysis of variance for stomatal conductance $(\mathrm{gs})$, intercellular $\mathrm{CO}_{2}$ concentration $(\mathrm{Ci})$, transpiration $(E), \mathrm{CO}_{2}$ assimilation rate $(A)$, intrinsic water use efficiency (WUEi) and instantaneous carboxylation efficiency $(\mathrm{CE} i)$ of mini-watermelon plants cv. Sugar Baby cultivated with saline water and phosphorus doses, at 60 days after sowing

\begin{tabular}{lccccccc}
\hline \multirow{2}{*}{ Source of variation } & \multirow{2}{*}{ DF } & \multicolumn{7}{c}{ Mean squares } \\
\cline { 3 - 7 } & & $g s$ & $C i$ & $E$ & $A$ & $W U E i$ & $C E i$ \\
\hline Saline levels (SL) & 4 & $0.010^{* *}$ & $769.67^{*}$ & $1.795^{*}$ & $68.81^{* *}$ & $1339.16^{* *}$ & $0.0003^{\text {ns }}$ \\
Linear regression & 1 & $0.032^{* *}$ & $2731.30^{*}$ & $6.491^{* *}$ & $272.37^{* *}$ & $5068.57^{* *}$ & $0.0015^{\text {ns }}$ \\
Quadratic regression & 1 & $0.003^{\text {ns }}$ & $57.75^{\text {ns }}$ & $0.563^{\text {ns }}$ & $1.20^{\text {ns }}$ & $270.68^{\text {ns }}$ & $0.00001^{\text {ns }}$ \\
Phosphorus doses (PD) & 3 & $0.001^{\text {ns }}$ & $4742.41^{*}$ & $0.511^{\text {ns }}$ & $15.64^{\text {ns }}$ & $40.22^{\text {ns }}$ & $0.0019^{* *}$ \\
Linear regression & 1 & $0.001^{\text {ns }}$ & $8780.43^{* *}$ & $0.109^{\text {ns }}$ & $6.10^{\text {ns }}$ & $11.57^{\text {ns }}$ & $0.001^{*}$ \\
Quadratic regression & 1 & $0.0008^{\text {ns }}$ & $2444.81^{*}$ & $0.526^{\text {ns }}$ & $13.18^{\text {ns }}$ & $48.02^{\text {ns }}$ & $0.001^{*}$ \\
Interaction (SL x PD) & 12 & $0.002^{\text {ns }}$ & $2054.53^{\text {ns }}$ & $0.249^{\text {ns }}$ & $24.81^{*}$ & $98.76^{\text {ns }}$ & $0.0008^{*}$ \\
Blocks & 2 & $0.0006^{\text {ns }}$ & $2330.51^{*}$ & $0.283^{\text {ns }}$ & $1.77^{\text {ns }}$ & $24.00^{\text {ns }}$ & $0.0011^{\text {ns }}$ \\
Residual & 38 & 0.001 & 604.99 & 0.238 & 6.88 & 75.85 & 0.0001 \\
CV $(\%)$ & & 17.54 & 11.44 & 14.26 & 16.84 & 12.41 & 19.01 \\
\hline
\end{tabular}

DF - degrees of freedom; CV (\%) - coefficient of variation; * significant at 0.05 probability level; ${ }^{* *}$ significant at 0.01 probability level; ns not significant. 
The stomatal conductance of watermelon plants decreased linearly with the increase in water salinity levels. Based on the regression equation (Figure 1A), there was a decrease in $g s$ of $6.76 \%$ per unit increase in ECw. Comparatively, plants irrigated using water with an $\mathrm{ECW}$ of $4.3 \mathrm{dS} \mathrm{m}^{-1}$ had a reduction in $g s$ of $27.60 \%\left(0.065 \mathrm{~mol} \mathrm{H}_{2} \mathrm{O}\right.$ $\left.\mathrm{m}^{-2} \mathrm{~s}^{-1}\right)$ in comparison to those irrigated with the lowest level of water salinity $\left(0.3 \mathrm{dS} \mathrm{m}^{-1}\right)$. The reduction in stomatal conductance may be related to the decrease in the turgor pressure of guard cells, due to the decrease in water absorption caused by the reduction in the osmotic potential of the soil solution. Stomatal closure is a protective strategy against salt stress, making it possible for the plant to save water and improve efficiency in its use. However, the lower gs leads to a reduction in $\mathrm{CO}_{2}$ diffusion through the leaf mesophyll. In addition, the supply of $\mathrm{CO}_{2}$ to RuBisCO (ribulose-1,5bisphosphate carboxylase oxygenase) is hampered, which predisposes the photosynthetic apparatus to increased energy dissipation and negative regulation of photosynthesis when plants are subjected to high light and temperature (Chaves, Flexas, \& Pinheiro, 2009). A decrease in stomatal conductance was also observed by Sá et al. (2016) in a study with bell pepper cv. All Big subjected to water salinity $(\mathrm{ECW}$ of 0.6 and $3.0 \mathrm{dS} \mathrm{m}^{-1}$ ).

In mini-watermelon plants, leaf transpiration also reduced linearly with an increase in water salinity levels and, according to the regression equation (Figure 1B), there was a reduction of $5.87 \%$ per unit increase in $\mathrm{ECW}$. When subjected to water salinity from $4.3 \mathrm{dS} \mathrm{m}^{-1}$, the reduction in $E$ was $23.93 \%\left(0.930 \mathrm{mmol} \mathrm{H}_{2} \mathrm{O} \mathrm{m}^{-2} \mathrm{~s}^{-1}\right)$ compared to those grown under ECw of $0.3 \mathrm{dS} \mathrm{m}^{-1}$. Reduction in the transpiration of mini-watermelon plants resulted from a decrease in stomatal conductance (Figure 1A) imposed by salt stress. It is likely that the reduction in leaf transpiration may, at least in part, be associated with the closure of stomata and with non-stomatal causes related to the osmotic and toxic effects of excess salts (Lúcio et al., 2013). However, stomatal closure contributes to a decrease in the flow of toxic ions $\left(\mathrm{Na}^{+}\right.$and $\left.\mathrm{Cl}^{-}\right)$within the transpiration flow in plants (Acosta-Motos et al., 2017). Furtado, Pereira, Andrade, Pereira e Silva (2012), in a study evaluating the effects of salt stress (ECw of 0.3 and $5.0 \mathrm{dS} \mathrm{m}^{-1}$ ) on the gas exchange of the watermelon cv. Crimson Sweet, concluded that the highest rate of leaf transpiration was observed in plants irrigated with $0.3 \mathrm{dS} \mathrm{m}^{-1}$ water.

Regarding the intrinsic water use efficiency of mini-watermelon plants (Figure 1C), it was verified that, as water salinity increased, there was a reduction in WUEi of $7.63 \%$ per unit increase in ECw. In plants grown under the highest level of ECW $\left(4.3 \mathrm{dS} \mathrm{m}^{-1}\right)$, WUEi was reduced by $31.25 \%$ (25.99 $\mu \mathrm{mol} \mathrm{CO}_{2} \mathrm{~mol} \mathrm{H}_{2} \mathrm{O}^{-1}$ ) compared to those subjected to water salinity of $0.3 \mathrm{dS} \mathrm{m}^{-1}$. As the intrinsic water use efficiency is obtained through the relationship between the $\mathrm{CO}_{2}$ assimilation rate and stomatal conductance, in which the observed values relate to the amount of carbon fixed by the plant for a given stomatal conductance, it is likely that the plants that have the capacity to maintain reduced water use efficiency under saline conditions are those that are sensitive to salt stress (Flowers \& Flowers, 2005).

Water salinity also promoted a linear reduction in the intercellular $\mathrm{CO}_{2}$ concentration of miniwatermelon plants (Figure 2A), equal to $2.21 \%$ per unit increase in ECW. There was a reduction of $20.00 \mu \mathrm{mol} \mathrm{H}_{2} \mathrm{O} \mathrm{m}^{-2} \mathrm{~s}^{-1}(8.90 \%)$ between plants irrigated using water with $\mathrm{ECW}$ of $4.3 \mathrm{dS} \mathrm{m}^{-1}$ as compared to those subjected to the lowest salinity level $\left(0.3 \mathrm{dS} \mathrm{m} \mathrm{m}^{-1}\right)$. It is likely that the reduction in $\mathrm{Ci}$ is related to the lower $\mathrm{CO}_{2}$ diffusion in the intercellular space of the leaf mesophyll, due to the stomatal closure caused by salt stress (W. J. D. Oliveira, Souza, Cunha, Silva, \& Veloso, 2017). With the closure of the stomata, initially there is a reduction in the intercellular $\mathrm{CO}_{2}$ concentration in the substomatal chamber and then, when the stress becomes severe, there is an increase in $\mathrm{Ci}$ (Romero, Alarcón, Valbuena, \& Galeano, 2017). Corroborating the results obtained in this study, S. S. da Silva et al. (2019) evaluated the gas exchange 
of watermelon cv. Sugar Baby under strategies of irrigation with saline waters (ECW of 0.8 and 3.2 $\mathrm{dS} \mathrm{m} \mathrm{m}^{-1}$ applied at different phenological stages) and found that irrigation using water with $\mathrm{ECw}$ of 3.2 $\mathrm{dS} \mathrm{m} \mathrm{m}^{-1}$ during the fruit maturation stage resulted in a reduction in the intercellular $\mathrm{CO}_{2}$ concentration.
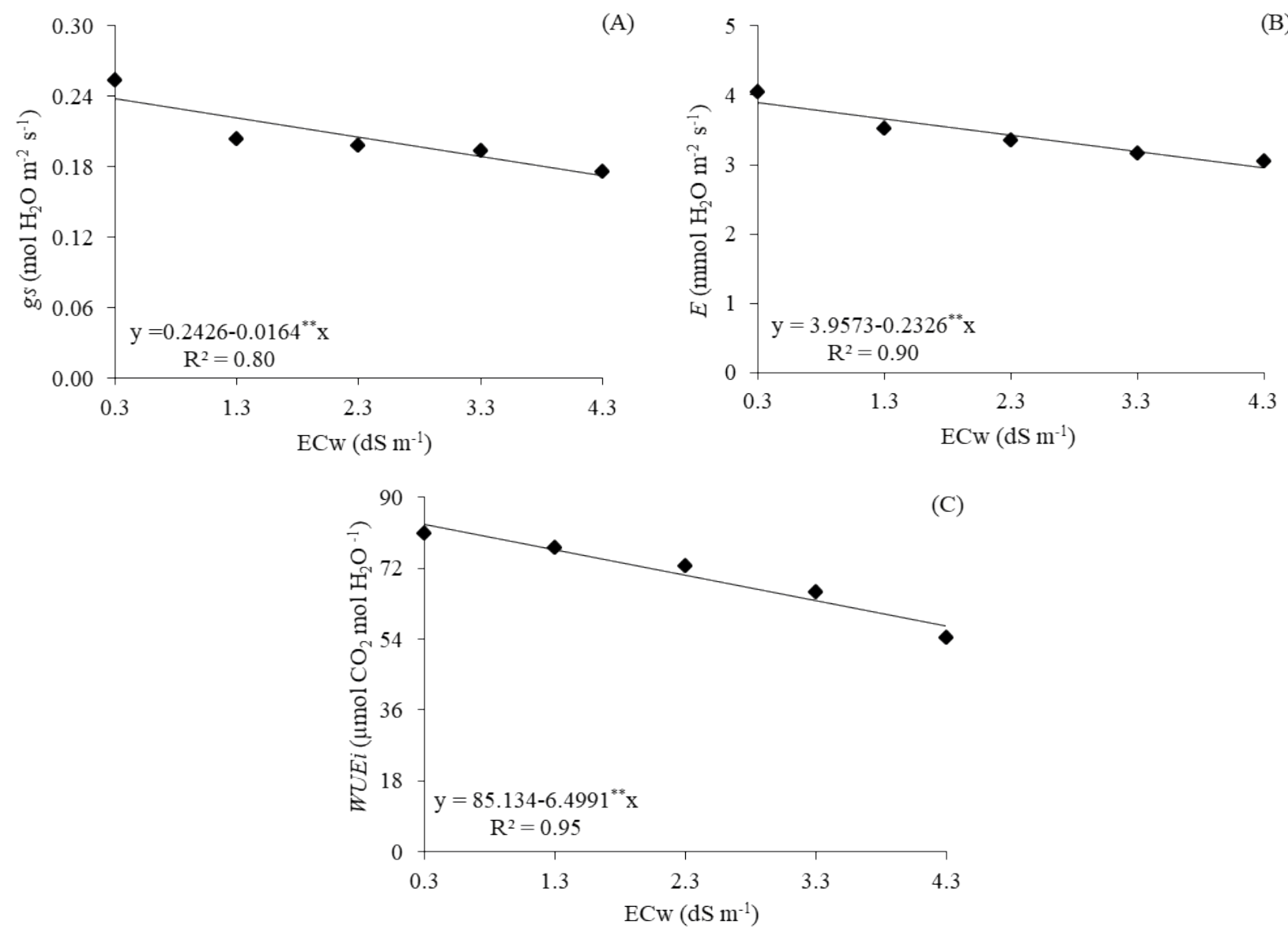

Figure 1. Stomatal conductance - gs (A), transpiration $-E(\mathrm{~B})$ and intrinsic water use efficiency - WUEi (C) of miniwatermelon plants cv. Sugar Baby as a function of water salinity - ECw, at 60 days after sowing.

Regarding the effects of phosphorus doses on the intercellular $\mathrm{CO}_{2}$ concentration of mini-watermelon plants (Figure 2B), the equation shows that a maximum estimated value of $227.35 \mu \mathrm{mol} \mathrm{H}_{2} \mathrm{O} \mathrm{m}^{-2}$ $\mathrm{s}^{-1}$ was obtained when plants were fertilized with an estimated dose of $73 \%$ of the $\mathrm{P}_{2} \mathrm{O}_{5}$ recommendation. There was a reduction of $32.91 \mu \mathrm{mol} \mathrm{H}_{2} \mathrm{O} \mathrm{m} \mathrm{m}^{-2}$ $\mathrm{s}^{-1}$ in $\mathrm{Ci}$ between plants grown at a dose of $120 \%$ and those fertilized with $60 \%$ of the $\mathrm{P}_{2} \mathrm{O}_{5}$ recommendation. Being a structural component of macromolecules, phosphorus plays a fundamental role in plant metabolism. It participates in energy- rich compounds, such as adenosine triphosphate (ATP), responsible for storing energy and donating electrons to maintain the biochemical phase of photosynthesis. It is also required for esterification reactions with sugars and other compounds involved in photosynthesis and respiration (Ceconi, Poletto, Lovato, \& Muniz, 2007), being a key element in various metabolic pathways and biochemical reactions, such as numerous stages of the $\mathrm{C}_{3}$ and $\mathrm{C}_{4}$ photosynthetic pathways and glycolysis (Kuwahara \& Souza, 2009). 

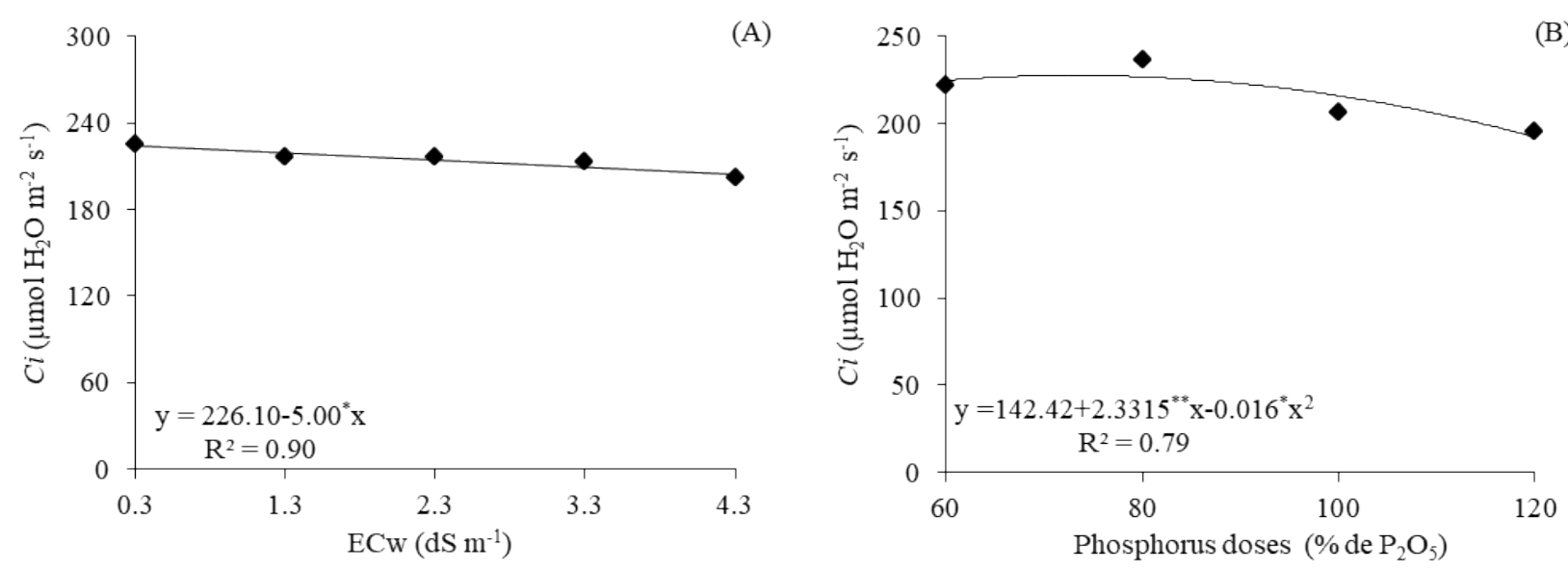

Figure 2. Intercellular $\mathrm{CO}_{2}$ concentration - $\mathrm{Ci}$ of mini-watermelon plants cv. Sugar Baby as a function of water salinity - ECW (A) and phosphorus doses (B) at 60 days after sowing.

The interaction between factors (SL x PD) significantly influenced the $\mathrm{CO}_{2}$ assimilation rate of mini-watermelon plants. According to the regression equations (Figure 3A), there were linear reductions in the $A$ of plants fertilized with 60 , 80,100 , and $120 \%$ of the $\mathrm{P}_{2} \mathrm{O}_{5}$ recommendation, which were respectively equal to $9.56,8.13,8.50$, and $7.75 \%$ per unit increase in ECw. Thus, plants irrigated with water from $4.3 \mathrm{dS} \mathrm{m}^{-1}$ reduced $A$ by $8.80,6.62,6.34$, and $4.83 \mu \mathrm{mol} \mathrm{m}^{-2} \mathrm{~s}^{-1}$ compared to those under the lowest salinity level $\left(0.3 \mathrm{dS} \mathrm{m}^{-1}\right)$. Therefore, it becomes evident that the decrease in $\mathrm{CO}_{2}$ assimilation rate in mini-watermelon depends on the dose of $\mathrm{P}_{2} \mathrm{O}_{5}$. The observed decrease in $\mathrm{CO}_{2}$ assimilation rate (Figure $3 \mathrm{~A}$ ) may be related to stomatal closure, as evidenced by stomatal conductance (Figure 1A) and by the reduction in the intercellular $\mathrm{CO}_{2}$ concentration (Figure 2A). The high concentration of ions such as $\mathrm{Na}^{+}$and $\mathrm{Cl}^{-}$in the leaves can also be considered as a factor that contributes to the reduction of $A$, due to damage to enzymes and structures of the membrane (Coelho, Simões, Salviano, Mesquita, \& Alberto, 2018), indicating that the decrease in $\mathrm{CO}_{2}$ assimilation rate is related to factors of stomatal and non-stomatal origin.
With regard to the instantaneous carboxylation efficiency (CEi) of watermelon (Figure 3B), it can be noted that, for plants fertilized with $\mathrm{P}_{2} \mathrm{O}_{5}$ doses of 60,80 , and $100 \%$ of the recommendation, the results were best described by a quadratic model, with maximum estimated value of $0.089 \mu \mathrm{mol}$ $\mathrm{m}^{-2} \mathrm{~s}^{-1} / \mu \mathrm{mol} \mathrm{m} \mathrm{m}^{-2} \mathrm{~s}^{-1}$ when plants were subjected to water salinity of 2.6, 2.0, and $2.5 \mathrm{dS} \mathrm{m} \mathrm{m}^{-1}$. However, under dose equivalent to $120 \%$ of the $\mathrm{P}_{2} \mathrm{O}_{5}$ recommendation, there was a linear and decreasing effect with a reduction of $14.89 \%$ per unit increase in ECw. When comparing the $C E i$ of plants fertilized with the highest $\mathrm{P}_{2} \mathrm{O}_{5}$ dose (120\%) and subjected to ECW of $4.3 \mathrm{dS} \mathrm{m}^{-1}$, it was possible to observe a reduction of $62.36 \%\left(0.0628 \mu \mathrm{mol} \mathrm{m} \mathrm{m}^{-2}\right.$ $\left.\mathrm{s}^{-1} / \mu \mathrm{mol} \mathrm{m} \mathrm{m}^{-2} \mathrm{~s}^{-1}\right)$ in comparison to those that were irrigated using water of the lowest salinity level $(0.3$ $\left.\mathrm{dS} \mathrm{m}^{-1}\right)$. The reduction in $C E i$ is an indication that factors of non-stomatal origin also influenced the photosynthetic activity of the plants, such as low activity of the enzyme Ribulose-1,5-bisphosphate carboxylase/oxygenase (RuBisCO), probably due to low substrate availability (ATP and NADPH) for enzyme activation and regeneration (Hussain, Luro, Costantino, Ollitrault, \& Morillon, 2012). 

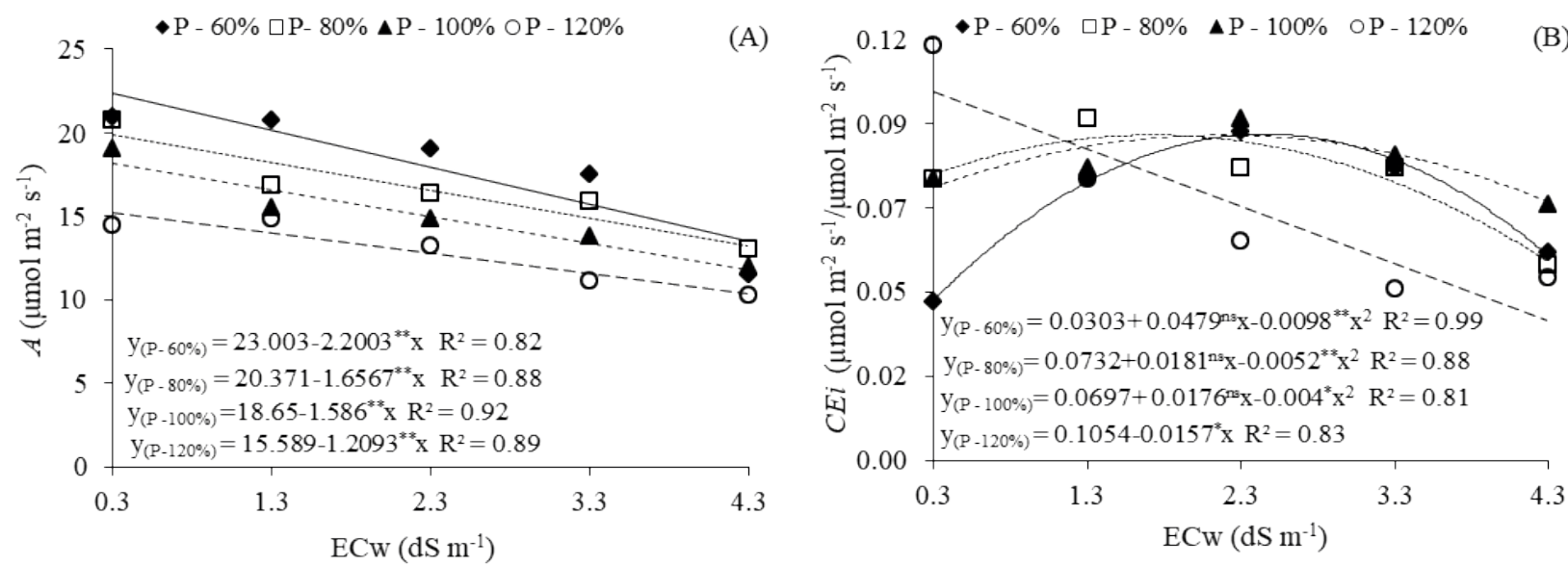

Figure 3. $\mathrm{CO}_{2}$ assimilation rate - $A$ (A) and instantaneous carboxylation efficiency - CEi (B) of mini-watermelon plants cv. Sugar Baby as a function of the interaction between water salinity levels $-\mathrm{ECW}$ and phosphorus doses at 60 days after sowing.

The summary of the analysis of variance (Table 3) shows a significant effect of the interaction between factors (SL x PD) on the main stem length of mini-watermelon plants. Water salinity levels significantly influenced all variables analyzed (MSL, SD, NL, FFW, FED, and FPD). Phosphate fertilization promoted a significant effect only on MSL and SD at 70 DAS.

Table 3

Summary of the analysis of variance for main stem length (MSL), stem diameter (SD), number of leaves (NL), fresh fruit weight (FFW), fruit equatorial diameter (FED) and fruit polar diameter (FPD) of mini-watermelon fruits cv. Sugar Baby cultivated with saline waters and phosphorus doses at 70 days after sowing

\begin{tabular}{lccccccc}
\hline \multirow{2}{*}{ Source of variation } & \multirow{2}{*}{ DF } & \multicolumn{7}{c}{ Mean squares } \\
\cline { 3 - 7 } & & MSL & SD & NL & FFW & FED & FPD \\
\hline Saline levels (SL) & 4 & $6331.53^{* *}$ & $7.19^{* *}$ & $1088.01^{* *}$ & $251046.98^{* *}$ & $19.08^{* *}$ & $17.53^{* *}$ \\
Linear regression & 1 & $24196.80^{* *}$ & $28.37^{* *}$ & $3996.30^{* *}$ & $940976.57^{* *}$ & $71.54^{* *}$ & $65.71^{* *}$ \\
Quadratic regression & 1 & $1080.21^{*}$ & $0.008^{\text {ns }}$ & $175.07^{\text {ns }}$ & $34935.91^{*}$ & $1.50^{\text {ns }}$ & $0.58^{\text {ns }}$ \\
Phosphorus doses (PD) & 3 & $1740.95^{* *}$ & $1.93^{*}$ & $75.24^{\text {ns }}$ & $9977.34^{\text {ns }}$ & $2.22^{\text {ns }}$ & $0.68^{\text {ns }}$ \\
Linear regression & 1 & $2610.75^{* *}$ & $0.04^{\text {ns }}$ & $14.74^{\text {ns }}$ & $69.88^{\text {ns }}$ & $2.85^{\text {ns }}$ & $0.41^{\text {ns }}$ \\
Quadratic regression & 1 & $1.35^{\text {ns }}$ & $3.16^{*}$ & $97.53^{\text {ns }}$ & $10984.46^{\text {ns }}$ & $3.10^{\text {ns }}$ & $0.61^{\text {ns }}$ \\
Interaction (SL x PD) & 12 & $956.38^{* *}$ & $0.30^{\text {ns }}$ & $60.28^{\text {ns }}$ & $10442.59^{\text {ns }}$ & $1.00^{\text {ns }}$ & $1.30^{\text {ns }}$ \\
Blocks & 2 & $561.80^{\text {ns }}$ & $0.001^{\text {ns }}$ & $11.57^{\text {ns }}$ & $9985.94^{\text {ns }}$ & $2.57^{\text {ns }}$ & $1.11^{\text {ns }}$ \\
Residual & 38 & 116.01 & 0.27 & 54.12 & 8269.16 & 0.86 & 0.76 \\
CV $(\%)$ & & 10.81 & 7.48 & 17.92 & 24.69 & 9.64 & 9.06 \\
\hline
\end{tabular}

DF - degrees of freedom; CV (\%) - coefficient of variation; * significant at 0.05 probability level; ${ }^{* *}$ significant at 0.01 probability level; ${ }^{\text {ns }}$ not significant. 
The main stem length of mini-watermelon plants was significantly affected by the interaction between factors (SL x PD). From the regression equations (Figure 4A), it is verified that the MSL data of plants fertilized with 60 and $80 \%$ of the $\mathrm{P}_{2} \mathrm{O}_{5}$ recommendation were described by a quadratic model, with maximum estimated values of 103.96 and $113.30 \mathrm{~cm}$ under ECw of 1.9 and $0.3 \mathrm{dS} \mathrm{m}^{-1}$, respectively. For plants that received 100 and $120 \%$ of $\mathrm{P}_{2} \mathrm{O}_{5}$, linear decreases were observed as the $\mathrm{ECW}$ levels increased, corresponding to 10.64 and $13.60 \%$ per unit increase in $\mathrm{ECW}$, i.e. equivalent reductions of 44.0 and $56.7 \%$ in the MSL of plants irrigated with $\mathrm{ECW}$ of $4.3 \mathrm{dS} \mathrm{m} \mathrm{m}^{-1}$ compared to those under water salinity of $0.3 \mathrm{dS} \mathrm{m}^{-1}$. The reduction in growth in plants under salinity can be attributed to osmotic stress caused by the reduction in the external water potential and to the ionic effect caused by the accumulation of ions in plant tissues (Lima, Nobre, Gheyi, Soares, \& Silva, 2014). Another factor that possibly contributed to the reduction in MSL was the competitive mechanism: $\mathrm{Na}^{+}$occuping the sites of absorption of $\mathrm{K}^{+}$and $\mathrm{Mg}^{2+}$, and the ion $\mathrm{Cl}^{-}$ acting on $\mathrm{N}$ and $\mathrm{P}$ absorption sites, inhibiting their absorption (Lucena, Siqueira, Martinez, \& Cecon, 2012) and, thereby, contributing to the reduction in plant growth.

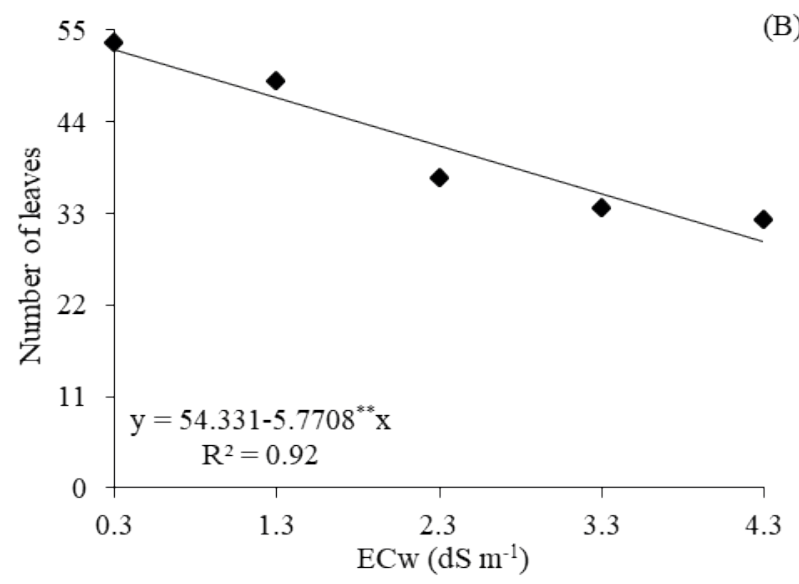

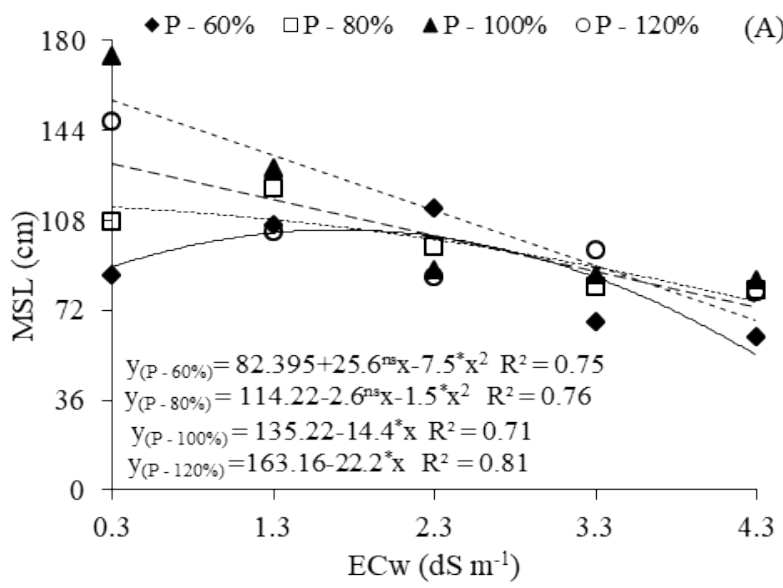

Figure 4. Main stem length - MSL of mini-watermelon plants cv. Sugar Baby as a function of the interaction between water salinity levels - ECw and phosphorus doses (A) and number of leaves as a function of ECw levels, 70 days after sowing.

The number of leaves of mini-watermelon plants decreased significantly with the increase in irrigation water salinity (Figure 4B), with a $10.62 \%$ reduction per unit increase in $\mathrm{ECw}$. By comparing the NL of plants subjected to $\mathrm{ECW}$ of $4.3 \mathrm{dS} \mathrm{m}^{-1}$ to that of plants under irrigation with the lowest salinity level $\left(0.3 \mathrm{dS} \mathrm{m}^{-1}\right)$, it was possible to note a reduction of 23.08 (43.88\%) leaves. The lower formation of leaves in plants grown under stress which occurred in the present study can be considered a morphological or anatomical alteration to maintain the absorption of water and nutrients under saline conditions and reduce transpiration and maintain a higher water content (Bezerra et al., 2018). Ribeiro, Sales, Eloi, Moreira e Sales (2012), in a study conducted to evaluate the effects of irrigation water salinity ( $\mathrm{ECw}$ ranging from 0.17 to $5.5 \mathrm{dS} \mathrm{m}^{-1}$ ) on the initial growth of watermelon, also found a reduction in the number of leaves, equal to 9.87\% per unit increase in $\mathrm{ECw}$.

Water salinity also inhibited the stem diameter growth of mini-watermelon plants. According to the regression equation (Figure 5A), the SD decreased by $5.98 \%$ per unit increase in ECw. When plants 
were subjected to a salinity of $4.3 \mathrm{dS} \mathrm{m} \mathrm{m}^{-1}$, their SD decreased by $24.36 \%$ (1.94 $\mathrm{mm})$ compared to those cultivated under the lowest salinity level $(0.3 \mathrm{dS}$ $\left.\mathrm{m}^{-1}\right)$. The decrease in the growth in stem diameter observed in plants under salt stress is possibly associated with energy expenditure due to various metabolic alterations such as lipid peroxidation, a reduction in chlorophyll content, an increased

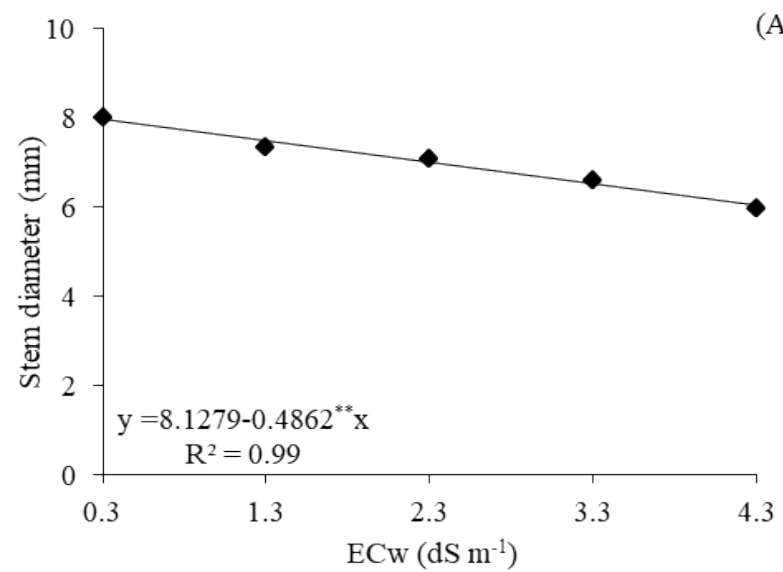

synthesis of reactive oxygen species, and enzymatic antioxidant activity (Queiroz, Sodek, \& Haddad, 2012). A reduction in the stem diameter of plants cultivated under salt stress has also been observed by Ribeiro et al. (2012) in watermelon cv. Crimson Sweet, by Araújo et al. (2016) in melon, and by Bezerra et al. (2018) in guava plants cv. Paluma.

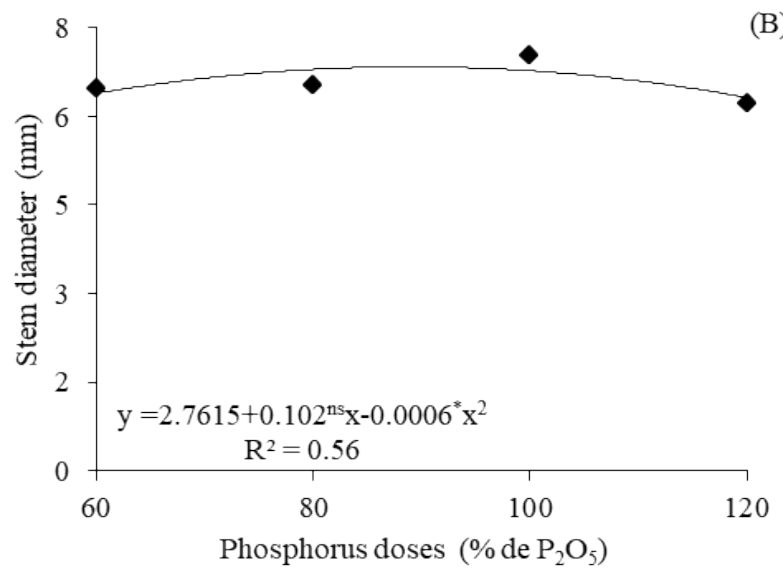

Figure 5. Stem diameter of mini-watermelon plants cv. Sugar Baby as a function of water salinity - ECw (A) and phosphorus doses (B) at 70 days after sowing.

Phosphorus doses significantly influenced the stem diameter of mini-watermelon plants. The regression equation (Figure 5B) shows that the maximum estimated value of SD $(7.09 \mathrm{~mm})$ was obtained in plants fertilized with $88 \%$ of the $\mathrm{P}_{2} \mathrm{O}_{5}$ recommendation and, from this dose, there was a downward trend. By comparing plants fertilized with $120 \%$ of $\mathrm{P}_{2} \mathrm{O}_{5}$ with those that received $60 \%$ of the recommendation, it was possible to observe a decrease of $0.36 \mathrm{~mm}$ in SD. Under salt stress conditions, the reduction in plant growth occurs due to the restriction in nutrient absorption caused by osmotic and ionic stresses, resulting from the high concentration of salts in the soil solution, in particular, the ions $\mathrm{Na}^{+}$and $\mathrm{Cl}^{-}$, the disorganization of the membrane system, and the production of reactive oxygen species (Lucena et al., 2012).

Regarding the fresh weight of mini-watermelon fruits (Figure 6A), the values decreased quadratically with increases in $\mathrm{ECw}$ levels, and the maximum estimated value (574.22 g per plant) was obtained in plants grown under the lowest water salinity level $\left(0.3 \mathrm{dS} \mathrm{m}^{-1}\right)$, decreasing sharply from that $\mathrm{ECw}$ level and reaching a minimum value (222.00 g per plant) at the highest $\mathrm{ECw}$ level $\left(4.3 \mathrm{dS} \mathrm{m}^{-1}\right)$. By comparing the FFW of plants irrigated with an ECW of $4.3 \mathrm{dS}$ $\mathrm{m}^{-1}$ with that of plants subjected to water salinity of $0.3 \mathrm{dS} \mathrm{m}^{-1}$, it was possible to note a reduction of $354.22(61.68 \%) \mathrm{g}$ per plant. The reduction in FFW may be related to difficulties in the absorption of water and nutrients by plants, arising due to the decrease in the osmotic potential of the soil solution caused by the excess of salts. This situation resulted in stomatal closure, observed in this study through the reduction in stomatal conductance (Figure 1A) and, consequently, had a negative effect on the $\mathrm{CO}_{2}$ assimilation rate (Figure $3 \mathrm{~A}$ ) resulting in the production of fruits with reduced weight. Costa et 
al. (2013), in an experiment conducted to evaluate the production and quality of three watermelon cultivars subjected to different levels of irrigation water salinity (ranging from 0.57 to $4.91 \mathrm{dS} \mathrm{m}^{-1}$ ), found that the number of fruits, yield, and weight reduced linearly with increasing water salinity.
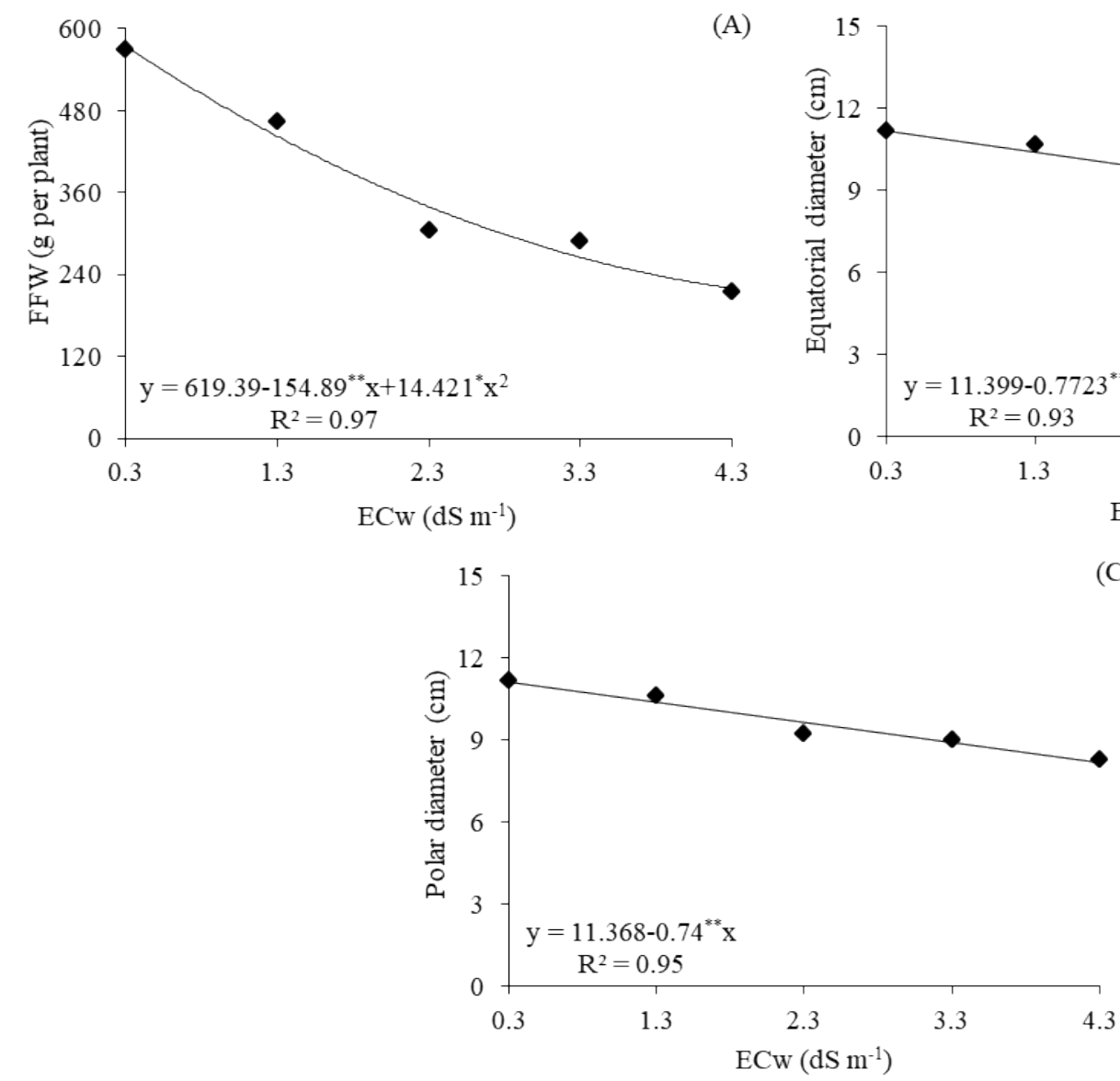

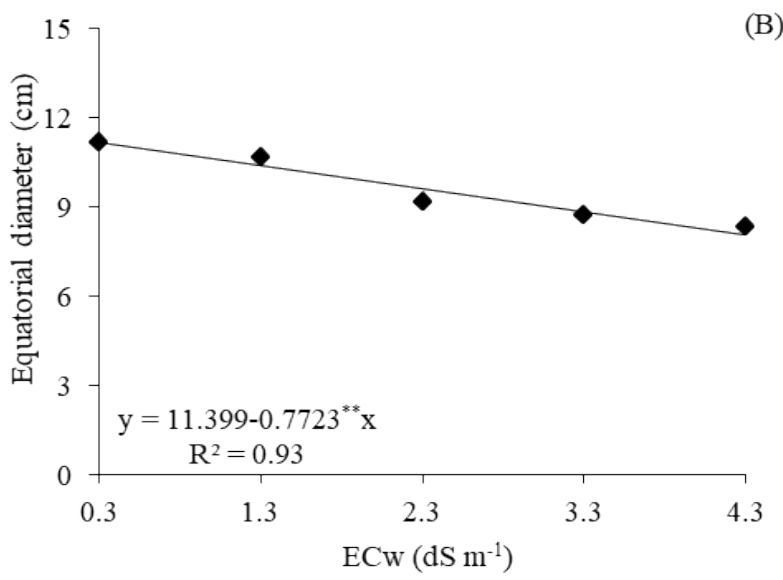

(C)

Figure 6. Fresh fruit weight - FFW (A), fruit equatorial diameter (B) and fruit polar diameter (C) of mini-watermelon plants cv. Sugar Baby as a function of water salinity - ECw, 70 days after sowing.

The equatorial (Figure 6B) and polar (Figure 6C) diameters of mini-watermelon fruits decreased linearly as the $\mathrm{ECw}$ levels increased, by 6.77 and $6.50 \%$ per unit increase in $\mathrm{ECw}$, respectively. In plants grown under ECw of $4.3 \mathrm{dS} \mathrm{m}^{-1}, \mathrm{FED}$ and FPD were reduced by 3.08 and $2.96 \mathrm{~cm}$ compared to those irrigated with $0.3 \mathrm{dS} \mathrm{m}^{-1}$ water. The production of fruits with a smaller diameter under salt stress conditions is also related to the diversion of energy for the maintenance of metabolic activities, as previously explained by Queiroz et al. (2012). S. S. da Silva et al. (2019) also observed the formation of fruits with a smaller diameter in plants irrigated using water with $\mathrm{ECw}$ of $3.2 \mathrm{dS} \mathrm{m}^{-1}$ in the vegetative and vegetative/flowering stages. According to these authors, this decrease in fruit size is a consequence of the reduction in water potential caused by excess salts in the soil.

\section{Conclusions}

Watermelon plants cv. Sugar Baby are sensitive to water salinity from $0.3 \mathrm{dS} \mathrm{m}^{-1}$, showing reductions in gas exchange, growth, and production. 
The reduction in the $\mathrm{CO}_{2}$ assimilation rate in watermelon plants cv. Sugar Baby is associated with factors of stomatal and non-stomatal origin.

Phosphorous doses equivalent to 73 and $88 \%$ of the recommendation promote an increase in the intercellular $\mathrm{CO}_{2}$ concentration and stem diameter, respectively, in mini-watermelon plants.

Fertilization with $\mathrm{P}_{2} \mathrm{O}_{5}$ doses ranging from 60 to $120 \%$ of the recommendation does not mitigate the effects of salt stress on the cultivation of watermelon cv. Sugar Baby.

\section{References}

Acosta-Motos, J. R., Ortuño, M. F., Bernal-Vicente, A., Diaz-Vivancos, P., Sanchez-Blanco, M. J., \& Hernandez, J. A. (2017). Plant responses to salt stress: adaptive mechanisms. Agronomy, 7(18), 1-37. doi: 10.3390/agronomy7010018

Alvarenga, C. F. de S., Silva, E. M. da, Nobre, R. G., Gheyi, H. R., Lima, G. S. de, \& Silva, L. de A. (2019). Morfofisiologia de aceroleira irrigada com águas salinas sob combinações de doses de nitrogênio e potássio. Revista de Ciências Agrárias, 42(1), 194205. doi: 10.19084/RCA18215

Araújo, E. B. G., Sá, F. V. da S., Oliveira, F. A. de, Souto, L. S., Paiva, E. P. de, Silva, M. K. do N., \& Brito, M. E. B. (2016). Crescimento inicial e tolerância de cultivares de meloeiro à salinidade da água. Revista Ambiente \& Água, 11(2), 463-471. doi: 10.4136/ ambi-agua.1726

Bezerra, I. L., Gheyi, H. R., Nobre, R. G., Lima, G. S. de, Santos, J. B. dos, \& Fernandes, P. D. (2018). Interaction between soil salinity and nitrogen on growth and gaseous exchanges in guava. Revista Ambiente \& Água, 13(3):e2130, 2018. doi: 10.4136/ ambi-agua. 2130

Ceconi, D. E., Poletto, I., Lovato, T., \& Muniz, M. F. B. (2007). Exigência nutricional de mudas de ervamate (Ilex paraguariensis A. St.-Hil.) à adubação fosfatada. Ciência Florestal, 17(1), 25-32. doi: 10. 5902/198050981932

Chaves, M. M., Flexas, J., \& Pinheiro, C. (2009). Photosynthesis under drought and salt stress: regulation mechanisms from whole plant to cell. Annals of Botany, 103(4), 551-560. doi: 10.1093/ aob/men 125
Coelho, D. S., Simões, W. L., Salviano, A. M., Mesquita, A. C., \& Alberto, K. da C. (2018). Gas exchange and organic solutes in forage sorghum genotypes grown under different salinity levels. Revista Brasileira de Engenharia Agrícola e Ambiental, 22(4), 231-236. doi: 10.1590/1807-1929/agriambi.v22n4p231-236

Costa, A. R. F. C. da, Medeiros, J. F. de, Porto, F. de Q., F ${ }^{\circ}$., Silva, J. S. da, Costa, F. G. B., \& Freitas, D. C. de (2013). Produção e qualidade de melancia cultivada com água de diferentes salinidades e doses de nitrogênio. Revista Brasileira de Engenharia Agrícola e Ambiental, 17(9), 947-954. doi: 10.1590/ S1415-43662013000900006

Ferreira, D. F. (2019). SISVAR: A computer analysis system to fixed effects split plot type designs. Revista Brasileira de Biometria, 37(4), 529-535, 2019. doi:10.28951/rbb.v37i4.450

Flowers, T. J., \& Flowers, S. A. (2005). Why does salinity pose such a difficult problem for plant breeders? Agricultural Water Management, 78(1), 15-24. doi: 10.1016/j.agwat.2005.04.015

Freitas, L. D. A., Figueirêdo, V. B., Porto, F. de Q.,

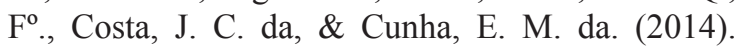
Crescimento e produção do meloeiro cultivado sob diferentes níveis de salinidade e nitrogênio. Revista Brasileira de Engenharia Agrícola e Ambiental, 18(Supl.), S20-S26. doi: 10.1590/S1415-4366200 7000300002

Furtado, G. de F., Pereira, F. H. F., Andrade, E. M. G., Pereira, R. R., Fo., \& Silva, S. S. da (2012). Efeito do nitrato de cálcio na redução do estresse salino em melancieira. Revista Verde de Agroecologia e Desenvolvimento Sustentável, 7(3), 33-40.

Gupta, B., \& Huang, B. (2014). Mechanism of salinity tolerance in plants: physiological, biochemical, and molecular characterization. International Journal of Genomics, 2014(1), 1-8. doi: 10.1155/2014/701596

Hernández, J. A. (2019). Salinity tolerance in plants: trends and perspectives. International Journal of Molecular Sciences, 20(10), 2408. doi: 10.3390/ijms20102408

Hussain, S., Luro, F., Costantino, G., Ollitrault, P., \& Morillon, R. (2012). Physiological analysis of salt stress behavior of citrus species and genera: low chloride accumulation as an indicator of salt tolerance. South African Journal of Botany, 81(1), 103-112. doi: 10.1016/j.sajb.2012.06.004

Instituto Brasileiro de Geografia e Estatística (2018). Área plantada, área colhida, quantidade produzida, rendimento médio e valor da produção das lavouras temporária. Recuperado de https://sidra.ibge.gov. br/ tabela/1612\#resultado 
Kuwahara, F. A., \& Souza, G. M. (2009). Fósforo como possível mitigador dos efeitos da deficiência hídrica sobre o crescimento e as trocas gasosas de Brachiaria brizantha cv. MG-5 Vitória. Acta Scientiarum. Agronomy, 31(2), 261-267. doi: 10.1590/S180786212009000200012

Lima, G. S. de, Nobre, R. G., Gheyi, H. R., Soares, L. A. dos A., \& Silva, A. O. da. (2014). Crescimento e componentes de produção da mamoneira sob estresse salino e adubação nitrogenada. Engenharia Agrícola, 34(5), 854-866. doi: 10.1590/S010069162014000500005

Lucena, C. C. de, Siqueira, D. L. de, Martinez, H. E. P., \& Cecon, P. R. (2012). Efeito do estresse salino na absorção de nutrientes em mangueira. Revista Brasileira de Fruticultura, 34(1), 297-308. doi: 10.1590/ S0100-29452012000100039

Lúcio, W. da S., Lacerda, C. F. de, Mendes, P. F., Fo., Hernandez, F. F. F., Neves, A. L. R., \& Gomes, E., $\mathrm{F}^{\mathrm{o}}$. (2013). Crescimento e respostas fisiológicas do meloeiro inoculado com fungos micorrízicos arbusculares sob estresse salino. Semina: Ciências Agrárias, 34(4), 1587-1602. doi: 10.5433/1679$0359.2013 v 34 n 4$ p 1587

Machado, R. M. A., \& Serralheiro, R. P. (2017). Soil salinity: effect on vegetable crop growth. Management practices to prevent and mitigate soil salinization. Horticulturae, 3(2), 30. doi: 10.3390/ horticulturae 3020030

Medeiros, J. F., Lisboa, R. A., Oliveira, M., Silva, M. J., Jr., \& Alves, L. P. (2003). Caracterização das águas subterrâneas usadas para irrigação na área produtora de melão da Chapada do Apodi. Revista Brasileira Engenharia Agrícola e Ambiental, 7(3), 469-472. doi: 10.1590/S1415-43662003000300010

Novais, R. F., Neves, J. C. L., \& Barros, N. F. (1991). Ensaio em ambiente controlado. In A. J. Oliveira (Ed.), Métodos de pesquisa em fertilidade do solo (Cap. 12, pp. 189-253). Brasília: EMBRAPA-SEA.

Oliveira, F. R. A., Oliveira, F. A. O., Medeiros, J. F., Sousa, V. F. L., \& Freire, A. G. (2010). Interação entre salinidade e fósforo na cultura do rabanete. Revista Ciência Agronômica, 41(4), 519-526. doi: 10.1590/ S1806-66902010000400003

Oliveira, W. J. D., Souza, E. R. D., Cunha, J. C., Silva, E. F. F., \& Veloso, V. D. L. (2017). Leaf gas exchange in cowpea and $\mathrm{CO}_{2}$ efflux in soil irrigated with saline water. Revista Brasileira de Engenharia Agricola e Ambiental, 21(1), 32-37. doi: 10.1590/1807-1929/ agriambi.v21n1p32-37
Queiroz, H. M., Sodek, L., \& Haddad, C. R. B. (2012). Effect of salt on the growth and metabolism of Glycine max. Brazilian Archives of Biology and Technology, 55(6), 809-817. doi: 10.1590/S151689132012000600002

Razaq, M., Zhang, P., Shen, H., \& Salahuddin. (2017). Influence of nitrogen and phosphorus on the growth and root morphology of Acer mono. PLoS One, 12(2), e0171321. doi: 10.1371/journal.pone.0171321

Ribeiro, A. de A., Sales, M. A. de L., Eloi, W. M., Moreira, F. J. C., \& Sales, F. A. de L. (2012). Emergência e crescimento inicial da melancia sob estresse salino. Revista Brasileira de Engenharia de Biossistemas, 6(1), 30-38. doi: 10.18011/bioeng2012v6n1p30-38

Richards, L. A. Diagnosis and improvement of saline and alkali soils. (USDA, Agriculture Handbook, 60). Washington: USDA, 1954. 160 p.

Romero, A. P., Alarcón, A., Valbuena, R. I., \& Galeano, C. H. (2017). Physiological assessment of water stress in potato using spectral information. Frontiers in Plant Science, 8(3), 1608. doi: 10.3389/fpls. 2017.01608

Sá, F. V. da S., Lima, G. S. de, Santos, J. B. dos, Gheyi, H. R., Soares, L. A. dos A., Cavalcante L. F., \& Souza, L. de P. (2016) Growth and physiological aspects of bell pepper (Capsicum annuum) under saline stress and exogenous application of proline. African Journal of Biotechnology, 15(36), 1970-1976. doi: 10.5897/AJB2016.1544

Saraiva, K. R., Viana, T. V. de A., Costa, S. C., Coelho, E. L., Caledônio, C. A., \& Lima, G. H. P. de (2013). Influência da densidade de plantio da cultura da melancia sobre suas características de produção, na chapada do Apodi, CE. Revista Brasileira de Agricultura Irrigada, 7(2), 128-135. doi: 10.7127/ RBAI.V7 N200012

Silva, N. C., Karasawa, M., Pires, M. M. M. L., Batista, P. F., Pimenta, R., Dias, R. C. S., \& Aragão, C. A. (2008). Qualidade pós-colheita de minimelancias submetidas a diferentes coberturas do solo. Horticultura Brasileira, 26(2), 5717-5720.

Silva, S. S. da, Lima, G. S. de, Lima, V. L. A. de, Gheyi, H. R., Soares, L. A. dos A., \& Lucena, R. C. M. (2019). Gas exchanges and production of watermelon plant under salinity management and nitrogen fertilization. Pesquisa Agropecuária Tropical, 49(1), e54822. doi: 10.1590/1983-40632019v4954822

Teixeira, P. C., Donagemma, G. K., Fontana, A., \& Teixeira, W. G. (2017). (Org.), Manual de métodos de análise de solo (3a ed.). Brasília, DF: EMBRAPA. 